\title{
Technology of Web GIS and Mobile GIS for Airport Business Area Development
}

\author{
Muhammad Ikhsan Setiawan ${ }^{1}$, Otto Fajarianto ${ }^{2}$, Robbi Rahim ${ }^{3}$, Janner Simarmata ${ }^{4}$, Dahlan Abdullah ${ }^{5}$, Ansari Saleh \\ Ahmar $^{6}$, Darmawan Napitupulu ${ }^{7}$, Heri Nurdiyanto ${ }^{8}$, Rahmat Hidayat ${ }^{9}$ \\ ${ }^{1}$ Narotama University, Department of Civil Engineering, Surabaya Jawa Timur 60117, Indonesia \\ ${ }^{2}$ STMIK Bina Sarana Global, Jakarta, Indonesia \\ ${ }^{3}$ School of Computer and Communication Engineering, Universiti Malaysia Perlis, Malaysia \\ ${ }^{4}$ State University of Medan, Indonesia \\ ${ }^{5}$ Universitas Malikussaleh, Department of Informatics, Aceh, Indonesia \\ ${ }^{6}$ Department of Statistics, Universitas Negeri Makassar, Indonesia \\ ${ }^{7}$ Research Center for Quality System and Testing Technology, Indonesian Institute of Sciences, Jakarta, Indonesia \\ ${ }^{8}$ Informatics Engineering Department, STMIK Dharma Wacana, Lampung Indonesia \\ ${ }^{9}$ Department of Information Technology, Politeknik Negeri Padang, Indonesia \\ usurobbi85@zoho.com,jannersimarmata@unimed.ac.id,dahlan@unimal.ac.id, ansarisaleh@unm.ac.id, \\ darwan.na70@gmail.com, herinurdiyanto@gmail.com,rahmat@polinpdg.ac.id
}

\begin{abstract}
Indonesia has 296 airports officially managed by the government, covering 13 airports managed by PT Angkasa Pura I, 13 airports are managed by PT Angkasa Pura II, 53 airports are managed by the National Army (TNI), 178 airports are managed by Airport Operator Unit of the Ministry of Transportation and lastly, 39 airports are managed by UPT Local Government. Using technology of web GIS and mobile GIS for airport business area development, help User in determining the airport in Indonesia that have the potential based on the local APBD and the local PDRB, in airport area and the potential of local business area development, more flexible and timely, that is real-time and provide easy-to-use information, can be visualized by mapping thematic, labeling, symbolizing, querying and preparing summary reports.
\end{abstract}

Keywords—web GIS; mobile GIS; airport business area

\section{INTRODUCTION}

Map is a source of information about the earth surveyed using geodesy techniques, map processing is scattered in various disciplines in which the map is included as a special image type [1] . digital methods for digital learning, today's digital media technology has given a significant effect [2]. Over the past decade many free software for storage, analysis and visualization, such as desktop GIS, remote sensing software, GIS servers, some of which should be considered are functionality, license types and limitations, developer features and community users, and more [3]. Smartphones have the ability to record GPS data systematically, spatially (GPS coordinates) and temporal information (speed and time) are used to calculate the possibility of data for a particular path [4]. Global Navigation System has changed share information and geospatial data in the field. Along with wireless networking technology, allow user-connected fields, and stream large geospatial data from web-servers, geospatial data is more flexible and timely, data using smartphone-based and webbased GIS systems, that is real-time and provide easy-to-use information, can be visualized by mapping thematic, labeling, symbolizing, querying and preparing summary reports [5]. more people with opportunities to contribute and consume information relevant to their current location, privacy implications associated with constant locational aware smartphone usage while applied researchers are measuring spatial cognitive abilities using empirically bound approaches, how smartphone users perceive implications associated with privacy and spatial cognitive abilities as a result of smartphone use for location based queries [6].

Indonesia has 296 airports officially managed by the government, covering 13 airports managed by PT Angkasa Pura I, 13 airports are managed by PT Angkasa Pura II, 53 airports are managed by the National Army (TNI), 178 airports are managed by Airport Operator Unit of the Ministry of Transportation and lastly, 39 airports are managed by UPT Local Government [7]

The purpose of this study to determine the location of airport in Indonesia using technology of web GIS and mobile GIS, the potential of local expenditure budget (APBD) and local Gross Domestic Product (PDRB). The benefits of this research to help User in determining the airport in Indonesia that have the potential based on the local APBD and the local PDRB, using technology of web GIS and mobile GIS for airport business area development.

\section{RESEARCH METHODOLOGY}

The population in this research is all airports managed by the government of 296 airports. The sampling technique was 
performed using stratified random sampling and 172 airports were produced. The Airport Performance variables including: Aircraft Arrival, Aircraft Departure, Passenger Departure, Passenger Arrival, Baggage Unloaded, Baggage Loaded, Cargo Unloaded, Cargo Loaded. The variable of APBD including: Revenue, Origin Revenue (PAD), Revenue of separated assets, Expenditure, Local Capital Expenditure, and Investment of Local Capital. The research variables include the variable of Gross Regional Domestic Product (GRDP) including: Water supply, Sewerage, Waste Management and Remediation Activities; Wholesale and Retail Trade; Repair of Motor Vehicles and Motorcycles; Accommodation and Food Service Activities; Financial and Insurance Activities; Business Activities; Public Administration and Defense, Compulsory Social Security; Education; Human Health and Social Work Activities; Other Services Activities; Gross Regional Domestic Product; Manufacturing; Electricity and Gas.

GIS has the ability to map and analyze spatial data with spatial analysis (spatial analysis) and analysis time (temporal analysis), generating an integrated analysis covering all aspects, in this research using technology of web GIS and mobile GIS to determine the location of airport and the potential of local business area development

\section{RESULT AND DISCUSSIONS}

From the analysis results on the map view can know which region has the potential of local expenditure budget (APBD) and local Gross Domestic Product (PDRB) in airport area and the potential of local business area development, as shown in the following figure,

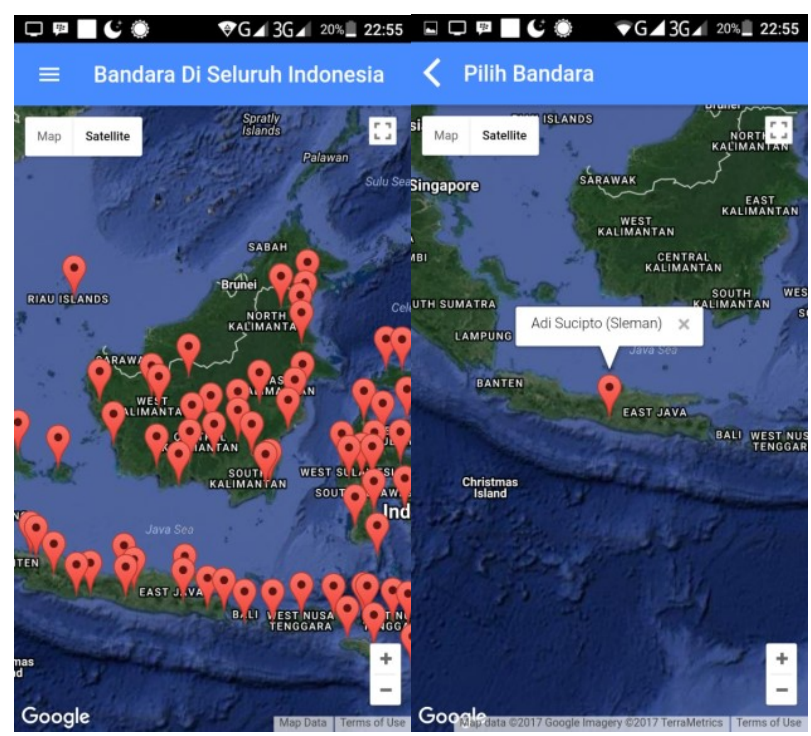

Fig. 1. Display Airport MAP in Indonesia
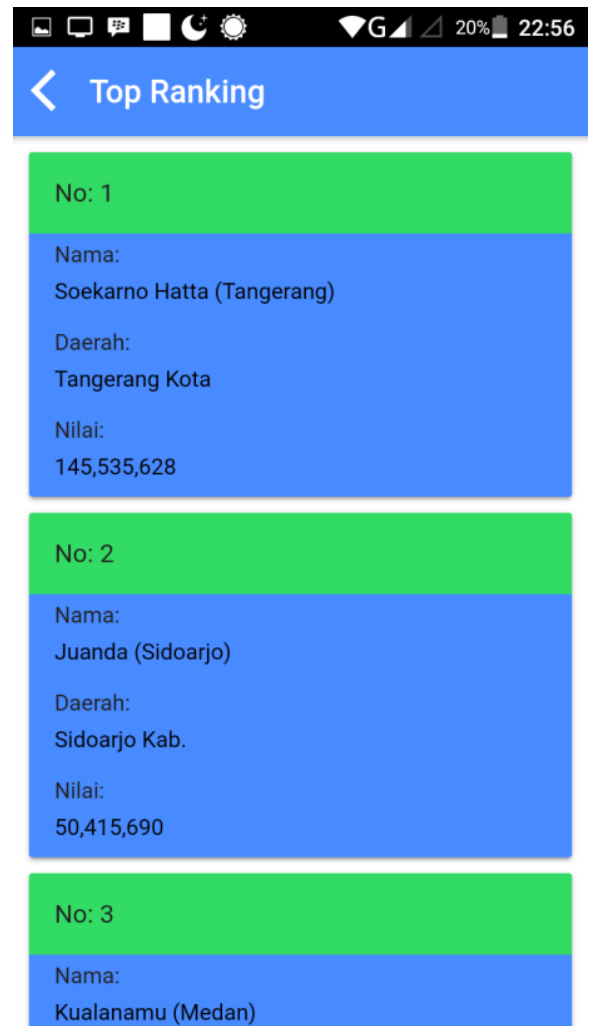

Fig. 2. Displaying Airport Data Based on Airport Ranking

Image above explains the data that appears click on the potential of local expenditure budget (APBD) and local Gross Domestic Product (PDRB) in airport area and the potential of local business area development using Web GIS. The data will shows 172 results, where this amount includes the area is potentially of local expenditure budget (APBD) and local Gross Domestic Product (PDRB)

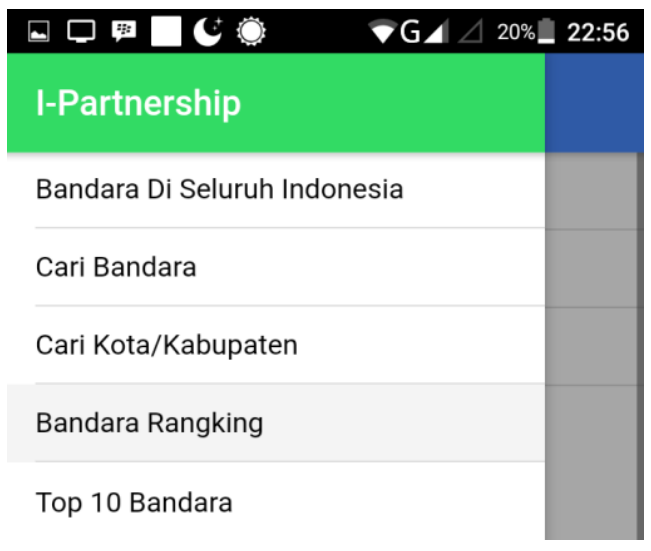

Fig. 3. Mobile Airport App Menu

Image above explains the data that appears click on the potential of local expenditure budget (APBD) and local Gross Domestic Product (PDRB) in airport area and the potential of local business area development using Mobile Android GIS. The data will shows 172 results, where this amount includes the area is potentially of local expenditure budget (APBD) and local Gross Domestic Product (PDRB). 


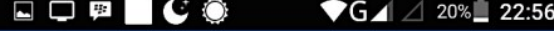

\section{$\equiv$ Top 10 Bandara}

\begin{tabular}{l} 
AIRPORT PERFORM \\
\hline 1. Soekarno Hatta (Tangerang) \\
2. Juanda (Sidoarjo) \\
3. Hasanuddin (Makassar) \\
4. Sepinggan (Balikpapan) \\
5. Kualanamu (Medan) \\
6. Ngurah Rai (Badung) \\
7. Sentani (Jayapura) \\
8. Hang Nadim (Batam) \\
9. Adi Sucipto (Sleman) \\
10. Sam Ratulangi (Manado) \\
\hline 1. Halim Perdanakusuma (Jakarta Timur) \\
2. Ngurah Rai (Badung) \\
\hline APBsein Sastranegara (Bandung)
\end{tabular}

Fig. 4. Showing the Best 10 Airport Ranking Data

Image above explains the data that appears click on the best 10 of potential of local expenditure budget (APBD) and local Gross Domestic Product (PDRB) in airport area and the potential of local business area development using Mobile Android GIS.

\section{CONCLUSIONS}

Using technology of web GIS and mobile GIS for airport business area development, help User in determining the airport in Indonesia that have the potential based on the local APBD and the local PDRB, in airport area and the potential of local business area development, more flexible and timely, that is real-time and provide easy-to-use information, can be visualized by mapping thematic, labeling, symbolizing, querying and preparing summary reports.

\section{ACKNOWLEDGMENT}

This paper is a part of a $\mathrm{PhD}$ Dissertation titled "Business Centre of Property Commercial Development Model of Airport Area in Indonesia" with Prof. Ir. Surjono Surjokusumo, M.Sc.F, Ph.D., Ir. Dadang M. Ma'soem, MSCE, Ph.D. and Dr. Ir. Johny Johan, M.Eng, MM., as the counselors.

\section{REFERENCES}

[1] Y.-Y. Chiang, S. Leyk, and C. A. Knoblock, "A Survey of Digital Map Processing Techniques," ACM Comput. Surv., vol. 47, no. 1, pp. 1-44, 2014.

[2] N. Marres, "Why Map Issues? On Controversy Analysis as a Digital Method," Sci. Technol. Hum. Values, vol. 40, no. 5, pp. 655-686, 2015.

[3] S. Steiniger and A. J. S. Hunter, "The 2012 free and open source GIS software map - A guide to facilitate research, development, and adoption," Computers, Environment and Urban Systems, vol. 39. pp. 136-150, 2013.

[4] M. Bierlaire, J. Chen, and J. Newman, "A probabilistic map matching method for smartphone GPS data," Transp. Res. Part C Emerg. Technol., vol. 26, pp. 78-98, 2013.

[5] K. Lwin, M. Hashimoto, and Y. Murayama, "Real-Time Geospatial Data Collection and Visualization with Smartphone," J. Geogr. Inf. Syst., vol. 6, no. April, pp. 99-108, 2014.

[6] B. Ricker, N. Schuurman, and F. Kessler, "Implications of smartphone usage on privacy and spatial cognition: academic literature and public perceptions," GeoJournal, vol. 80, no. 5, pp. 637-652, 2015.

[7] PT Angkasa Pura I, 2016 annual report. PT Angkasa Pura I (Persero), 2017. 